\title{
Air quality at two stations (Gdynia and Rumia) located in the region of Gulf of Gdansk during periods of intensive smog in Poland
}

\author{
Kinga Wiśniewska ${ }^{1}$ - Anita Urszula Lewandowska ${ }^{1}$ (I) $\cdot$ Marta Staniszewska $^{1}$
}

Received: 15 April 2019 / Accepted: 9 May 2019 / Published online: 20 June 2019

(C) The Author(s) 2019

\begin{abstract}
The study was conducted to establish whether an extremely high concentration of aerosols occurred in the region of the Gulf of Gdansk at the very end of 2016, and if so which factors determined it. This period was notable in terms of intensity of smog episodes across the rest of Poland. The main goal was to consider pollution sources affecting two nearby stations in the area, which is usually characterised by better air quality than other parts of the country. To achieve this, concentrations of PM1 and PM2.5 were studied in Gdynia and PM10 concentration was measured in Rumia from 22 December 2016 to 22 January 2017. Concentrations of OC, EC, PAHs and major ions were also examined in order to indicate the origin of pollutants. The average daily concentration ranged $6.0-50.0 \mu \mathrm{g} \cdot \mathrm{m}^{-3}$ for PM1 and 8.3-61.9 $\mu \mathrm{g} \cdot \mathrm{m}^{-3}$ for PM2.5 in Gdynia, and 8.6-71.9 $\mu \mathrm{g} \cdot \mathrm{m}^{-3}$ for PM10 in Rumia. High concentrations of PM1 and PM2.5, classified as values higher than $25 \mu \mathrm{g} \cdot \mathrm{m}^{-3}$, were noted 4 times. The 24-h limit value of PM10 was exceeded 3 times. Even though the highest aerosol concentration obtained in our results exceeded the limit value by $150 \%$, it was nevertheless lower than in other Polish regions at the same time. This was due to dissimilar meteorological conditions, heavy snowfall and the landfall of Hurricane Barbara. However, high PAH concentrations in aerosols measured in Gdynia and Rumia indicate poor air conditions despite there being a relatively low average concentration of PM at the same time.
\end{abstract}

Keywords $\mathrm{PM}_{1-10} \cdot$ Chemical indicators $\cdot$ Air quality $\cdot$ Hurricane influence $\cdot$ Smog episodes

\section{Introduction}

Air pollution is still a very serious and important scientific problem as it has a wide-ranging impact on the whole environment. High particulate matter concentrations can affect vegetation and materials, as well as impacting on visibility and climate change (CIEP 2016). Another consequence of poor air quality accompanied by high concentrations of PM10/PM2.5 can be increased rates of morbidity and mortality. For human health, small particles with diameter $<2.5 \mu \mathrm{m}$ are particularly dangerous as they can penetrate deeply into the lungs and be transported directly into the bloodstream (Kennedy 2007; Ćwiklak et al. 2009; Pio et al. 2008; Szewczyńska et al. 2013; Hassanvand et al. 2015; Witkowska et al. 2016a). Health effects depend on the length of time for which a subject is exposed to high concentrations of particles. Short-term exposure results in

Anita Urszula Lewandowska

a.lewandowska@ug.edu.pl

1 Institute of Oceanography, University of Gdansk, Al. Marszałka J. Piłsudskiego 46, 81-378 Gdynia, Poland rapid reaction, e.g. cough, asthma severity, acute respiratory response and decreased lung function, while long-term exposure causes chronic diseases, including asthma, COPD, chronic bronchitis, emphysema and even cancers (Bruce et al. 2000; Kennedy 2007).

Many countries, including China, have made an effort to reduce atmospheric pollution, including PMx (Chen et al. 2018; Gordon et al. 2018; Torres et al. 2018). According to Awe et al. (2015), Santiago (Chile) - an example of a city overwhelmed with smog - significantly improved air quality over 20 years by adopting emission controls on factories and cars, cleaner public transport and the use of cleaner gas and energy sources. The European Union has also tightened its requirements for the reduction of national emissions of major pollutants, including sulphur (mainly sulphur dioxide), nitrogen oxides, volatile organic compounds and ammonia. The last directive issued by the European Parliament, the socalled CAFE directive (2008/50/EC; EEA 2014), connected all previous directives and was supplemented to include PM2.5. This directive is concentrated on ambient air quality and attaining cleaner air for Europe (http://www.unece.org). In Poland, air quality improvement is still an open question, even if there is no longer a problem with the emission of sulphur 
oxides or nitrogen as was the case at the end of the twentieth century (CIEP 2016). In 1990, the national emissions of $\mathrm{SO}_{2}$ and $\mathrm{NO}_{\mathrm{x}}$ were $2700 \mathrm{Gg}$ and $1100 \mathrm{Gg}$ respectively but by 2016, these values had dropped to $580 \mathrm{Gg}$ and $726 \mathrm{Gg}$ (KOBIZE 2016 and 2018). Currently, the biggest air pollution issue in Poland is the high level of PM10 and PM2.5 and benzo(a)pyrene, which is included in their composition. In cases of long-term exposure, one in every seven European citizens breaths the air and this does not satisfy the principles of the CAFE directive (EEA 2014). The rate for Poland could be even worse, with air quality in this country looking bad against the general European background. According to the World Health Organisation rankings in 2016, 33 of the 50 most polluted towns in Europe were located in Poland.

The highest aerosol concentrations are noted in the south of Poland. Regardless of the location, the concentration of aerosols in Poland increases during the heating period (Ćwiklak et al. 2009; Lewandowska et al. 2010; Rogula-Kozłowska et al. 2013; Rogula-Kozłowska et al. 2014; Witkowska et al. 2016b). January 2017 was exceptionally cold and snowy across the whole of Europe, with a polar airmass stretching from Russia across eastern Europe into south-eastern Europe. However, there is no information concerning severe smog episodes in Europe as occurred in Poland. For example, on 8 January 2017, the PM2.5 limit value which is set at $25 \mu \mathrm{g} \cdot \mathrm{m}^{-3}$ was exceeded by $592 \%$ in Krakow and $1278 \%$ in Katowice. Meanwhile, PM10 concentration in two other Polish towns, Zabrze and Pszczyna, reached $1016 \%$ and $1008 \%$ of the norm, respectively $\left(50 \mu \mathrm{g} \cdot \mathrm{m}^{-3}\right)$. The Polish National Health Fund (NFZ) cited such bad air quality as an important factor in increasing mortality in Poland. In 2017, total mortality amounted to 405,600 and was $3.8 \%$ higher than in 2016. In January 2017 alone, when high levels of aerosols occurred, 44,400 deaths were recorded. This number was greater by $23.5 \%$ in comparison with January 2016 (Department of Analysis and Strategy; NFZ 2018). The NFZ sees the reason as being the overlap of a number of adverse factors in January 2017, e.g. the average PM10 concentration was at its maximum record level, while average air temperature was lower compared with similar periods over the last few years. Additionally, there was a peak of flu incidences in Poland during this month.

Although it is commonly said that, in the coastal zone of the sea, the air quality is better than in other regions of Poland, high concentration episodes of PM10, PM2.5 and PAHs, as a constituent part, were also noted (Lewandowska et al. 2010; Staniszewska et al. 2013; Witkowska et al. 2016b). This is due to the fact that, in the urbanised coastal Baltic Sea zone, there are many sources of pollutant emissions (Wiśniewska et al. 2017; Lewandowska et al. 2018a). In consideration of the above, the aim of our study was to determine whether extremely high concentration of aerosols occurred in the region of Gulf of Gdansk (Gdynia) and surroundings (Rumia) on the cusp of 2016 and 2017, when severe smog situations were being noted in other parts of Poland. To establish the source of elevated concentrations of aerosols, several chemical and meteorological factors were taken into account including PAHs. Many aromatic compounds are suspected mutagens and carcinogens, and some of them may also cause acute health effects (Alves et al. 2017). The source of their origin and the connections which they enter into in aerosols, especially in their highest concentrations, seems to be extremely important in the aspect of human health and quality of life. There is still a lack of publications, especially on small PM1 but also on PM2.5 aerosols, and not only in extremely polluted Poland.

\section{Materials and methods}

\section{Sampling}

Parallel measurements of PM2.5 and PM1 were conducted in Gdynia in a 24-h cycle. The sampling period lasted from 22 December 2016 to 22 January 2017. Samples were collected $20 \mathrm{~m}$ above sea level on the roof of the Institute of Oceanography building (IO UG; Gdansk University) (Fig. 1), a location which possesses the characteristics of a highly industrialised and coastal city (it is situated about $1 \mathrm{~km}$ from the Gulf of Gdansk) but still stands in the centre of an urbanised area (Witkowska et al. 2016b). There are two other large cities in close proximity to Gdynia: Gdansk and Sopot. Altogether, the population of the so-called Tri-city agglomeration amounts to nearly 1 million (http://stat.gov.pl/en/ 2017). The IO UG station is surrounded by 8 schools, which leads to heightened traffic in the area, especially in the morning and afternoon hours. The nearest one is located at a distance of $128 \mathrm{~m}$, and the farthest $690 \mathrm{~m}$ from the measuring station. The research station is also surrounded by a number of communication routes, the largest of which is the Tri-city ring road located $6 \mathrm{~km}$ south-west of IO UG. Traffic on this road can reach up to 100,000 cars per day. Intense traffic (between 37 and 45 thousand per day) also characterises the largest commercial street in Gdynia, which is located 300 m away from the station (www.bdl.stat.gov.pl). In the region, there is also a well-developed ship repair yard and harbour. The nearest port is located to the north of the sampling station, at a distance of $3 \mathrm{~km}$. Within a radius of $10 \mathrm{~km}$, there is both a power plant and a local heat production plant.

The second measurement station, where PM10 samples were collected, was located in Rumia. The sampling period was parallel to the sampling in Gdynia (from 22 December 2016 to 22 January 2017 in a 24-h cycle). Sample collection took place in the area of the Education and Revalidation Centre in the town centre, which is situated close to the train station and a shopping mall. Rumia is located about $10 \mathrm{~km}$ from the coastal zone and $12 \mathrm{~km}$ from Gdynia, and its population amounts to 46 thousand (http://stat.gov.pl/en/2017). 


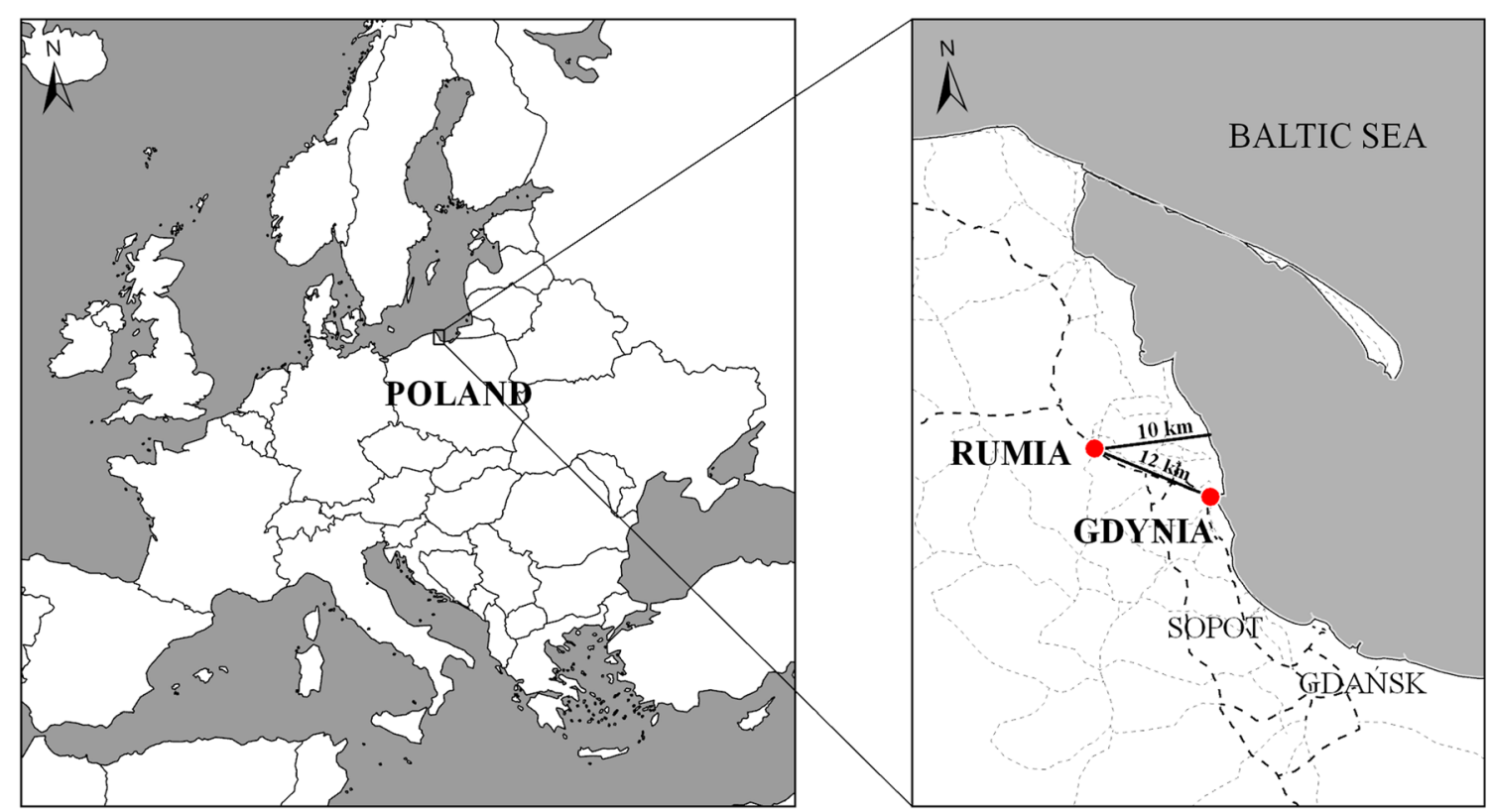

Fig. 1 Measurement stations in Gdynia and Rumia

Traffic in the town has a regional character, although car usage for work/school/shopping purposes is on a typical level and a bypass between the Tri-city and Kashubia runs through the town centre (68 thousand cars per day; www.bdl.stat.gov.pl). Rumia represents a less industrialised city than Gdynia, but nevertheless, within a radius of $10 \mathrm{~km}$, there is a boiler factory and a padding factory, both of which may be potential sources of pollution. The city is dominated by buildings with individual heating systems.

In Gdynia, samples of PM1 and PM2.5 were collected in parallel on Pallflex Tissuquartz filters of 47-mm diameter using low volume $\left(2.3 \mathrm{~m}^{3} \mathrm{~h}^{-1}\right)$ HYDRA Dual Sampler (FAI Instruments). In Rumia, PM10 sampling was performed on Q-MA Whatmann quartz filters using a similarly low volume $\left(2.3 \mathrm{~m}^{3} \mathrm{~h}^{-1}\right.$ ) LVS-16 Sampler (Umwelttechnik MCZ GmbH). Thirty-two aerosol samples of every size fraction were collected. Before sampling, all filters were preheated $\left(550{ }^{\circ} \mathrm{C}\right.$ for $6 \mathrm{~h}$, at minimum) in a furnace to eliminate volatile impurities and reduce blank values. Every procedure connected with weight measurements was performed with an accuracy of $10^{-5} \mathrm{~g}$ using the XA balance (RADWAG) at a temperature of $23 \pm 2{ }^{\circ} \mathrm{C}$ and a relative humidity of $40 \pm 5 \%$ (Lewandowska et al. 2010; Witkowska et al. 2016a; Witkowska et al. 2016b). The limit of quantification (LOQ) was set at $0.12 \mu \mathrm{g}, 0.15 \mu \mathrm{g}$ and $0.16 \mu \mathrm{g}$ per filter, for PM1, PM2.5 and PM10 respectively (20 replicates in each case). The uncertainty of the method was $<5.0 \%$ (at a certainty level of $99 \%$ ).

\section{Chemical analysis}

In every aerosol fraction, $\mathrm{OC}$ and $\mathrm{EC}$ concentrations were analysed using the thermo-optic method (Sunset Laboratory Inc., the EUSAAR2 protocol). This method enables selective determination of the concentration of carbon with an accuracy of $1 \mu \mathrm{g} \mathrm{C}$ (Cavalli et al. 2010). In addition to automatic calibration, an external standard (99.9\% sugar solution) was analysed every 10-15 samples (Schmid et al. 2001; Cavalli et al. 2010). The detection limit of the method was set at $2 \mu \mathrm{g}(n=12)$, and the analysis error was less than $8 \%$ (at a confidence interval of $99 \%$ ). The analytical error of the method was 4.5\% (Schmid et al. 2001; Cavalli et al. 2010; Witkowska et al. 2016b; Wiśniewska et al. 2017).

Concentrations of five PAHs (benzo(a)pyrene, benzo(a)anthracene, fluoranthene, pyrene and chrysene) were determined by means of high-performance liquid chromatography using a Dionex UltiMate 3000 analyser with a fluorescence detector (benzo(a)pyrene $\lambda$ ex. $=296 \mathrm{~nm}, \lambda \mathrm{em} .=408 \mathrm{~nm}$; fluoranthene and pyrene $\lambda$ ex. $=270 \mathrm{~nm}, \lambda \mathrm{em} .=440 \mathrm{~nm}$; benzo(a)antracene and chrysene $\lambda$ ex. $=275 \mathrm{~nm}, \lambda \mathrm{em} .=$ $380 \mathrm{~nm}$ ) (Staniszewska et al. 2013). The isolation of PAHs was conducted by means of solvent extraction (acetonitrile:dichloromethane 3:1 v/v) in an ultrasonic bath (Staniszewska et al. 2013). The concentration values for the standard curve ranged from 0.125 to $10 \mathrm{ng} \mathrm{cm}^{-3}$. The limit of quantification was $0.01 \mathrm{ng} \mathrm{cm}^{-3}$. The recovery determined against the reference material (SRM-2585) was 83\%, 78\%, 91\%, $91 \%$ and 99\% for $\mathrm{BaP}, \mathrm{FLA}, \mathrm{PYR}, \mathrm{BaA}$ and $\mathrm{CHR}$ respectively (Staniszewska et al. 2013; Lewandowska et al. 2018b).

The ions $\mathrm{NO}_{3}{ }^{-}$and $\mathrm{SO}_{4}{ }^{2-}$ were determined by ion chromatography 881 Compact IC pro (Metrohm) in accordance with Polish Standard PrPN-EN No 10304-1. For sulphates and nitrates, the limit of detection was $0.1 \mu \mathrm{g} \cdot \mathrm{m}^{-3}$ and $0.2 \mu \mathrm{g} \cdot \mathrm{m}^{-3}$ respectively, and the error of the method was $4.7 \%$ and $5.5 \%$. In all cases, a confidence level of $99 \%$ was assumed (Falkowska and Lewandowska 2004). 


\section{Characterisation of meteorological conditions}

The measurements were supplemented by meteorological parameters (wind speed and direction, relative humidity and air temperature, amount of precipitation, atmospheric pressure) obtained for both stations, Gdynia and Rumia, from ARMAAG (https://armaag.gda.pl/) (Table 1).

In order to determine the movement of air masses, the HYSPLIT model developed by NOAA was used (www.arl. noaa.gov/ready/hysplit4.html). A detailed description of the trajectories has been presented in previous papers (Lewandowska et al. 2010; Lewandowska et al. 2013).

\section{Statistical analysis}

Air quality was analysed in terms of temporal patterns which included daily and monthly cycles both in Rumia and Gdynia. For both PM1 and PM2.5, number of samples was equal to 32 and for PM10, it was 30. Statistical analysis was performed using the OpenAir package for R (Carslaw and Ropkins 2012).

\section{Results and discussion}

\section{Concentration of PM1 and PM2.5 in the air of Gdynia and PM10 in the air of Rumia}

In Gdynia, in the period between 22 December 2016 and 22 January 2017, the daily concentration of PM1 ranged from 6.0 to $50.0 \mu \mathrm{g} \cdot \mathrm{m}^{-3}(15.1 \pm 10.1)$ and the concentration of PM2.5 ranged from 8.3 to $61.9 \mu \mathrm{g} \cdot \mathrm{m}^{-3}(20.1 \pm 12.1)$. In this same period, the concentration of PM10 measured in Rumia, located $12 \mathrm{~km}$ to the north-west of Gdynia, ranged from 8.6 to $71.9 \mu \mathrm{g} \cdot \mathrm{m}^{-3}(27.9 \pm 16.5)$ (Table. 2).

Concentrations of aerosols are restricted by European guidelines (2008/80/WE) to $25 \mu \mathrm{g} \cdot \mathrm{m}^{-3}$ for PM2.5 (annual average), and $40 \mu \mathrm{g} \cdot \mathrm{m}^{-3}$ and $50 \mu \mathrm{g} \cdot \mathrm{m}^{-3}$ for PM10 (annual and daily values, respectively). As a daily norm for PM2.5 does not exist, it is not possible to define an exceedance of daily concentration. PM1 is a rarely studied fraction and is not covered by legal regulation at all.
Considering that the smaller the particles, the greater their negative impact on human health, for the purposes of this publication, we assumed that the daily average value of PM1 and PM2.5 should not exceed the annual PM2.5 limit value $\left(25 \mu \mathrm{g} \cdot \mathrm{m}^{-3}\right)$. In Gdynia, daily concentrations of PM1 and PM2.5 exceeded $25 \mu \mathrm{g} \cdot \mathrm{m}^{-3}$ four times during the entire study period (22 December 2016, and 9-11 January 2017). Meanwhile in Rumia, the daily norm of PM10 $\left(40 \mu \mathrm{g} \cdot \mathrm{m}^{-3}\right)$ was exceeded three times $(08.01$, 10.01 and 11.01.2017). In comparison, however, in 9 other Polish cities during the same period, PM10 concentration managed to exceed the alarm threshold set at $200 \mu \mathrm{g}$. $\mathrm{m}^{-3}$. For example, in the towns of Koscierzyna and Slupsk, which are both located in the same voivodeship as the measurement stations, the normative value of PM10 was exceeded 10 times and 3 times, respectively, during the entire study period.

In the case of PM2.5, it was even more frequent. In Kościerzyna, between 22 December 2016 and 22 January 2017 , the value of $25 \mu \mathrm{g} \cdot \mathrm{m}^{-3}$ was exceeded 17 times, and in Słupsk 11 times (CIEP, http://powietrze.gios.gov.pl/ pjp). In Koscierzyna, both aerosol fractions exceeded the proscribed concentrations during an episode from 9-11 January, reaching $57 \mu \mathrm{g} \cdot \mathrm{m}^{-3}$ in PM2.5 and $71 \mu \mathrm{g} \cdot \mathrm{m}^{-3}$ in PM10. In Stupsk during the mentioned episode, only the PM2.5 concentration was above the norm, reaching $43 \mu \mathrm{g} \cdot \mathrm{m}^{-3}$, while PM10 was at $48 \mu \mathrm{g} \cdot \mathrm{m}^{-3}$. Both cities are located further away from the sea $(50 \mathrm{~km}$ and $17 \mathrm{~km}$ ) than Gdynia and Rumia.

High aerosol concentration can be caused by unfavourable synoptic conditions and elevated anthropogenic emissions. These factors played an important role in creating high PM10 concentration, reaching up to $372 \mu \mathrm{g}$. $\mathrm{m}^{-3}$ and $481 \mu \mathrm{g} \cdot \mathrm{m}^{-3}$, during measurements conducted in Polish urban areas in January 2009 and 2010, respectively (Reizer and Juda-Rezler 2016). Garcia et al. (García et al. 2018) noted that PM2.5 and PM10 concentrations peak during the morning and the evening hours, which serves as evidence of the impact of traffic. One of the most important meteorological parameters influencing air quality is advection. For instance, increased PM concentrations noted by
Table 1 Meteorological condition from 22.12.2016 to 22.01.2017 measured in Gdynia and Rumia

\begin{tabular}{|c|c|c|c|c|}
\hline \multirow[t]{2}{*}{ Variable } & \multicolumn{2}{|l|}{ Gdynia } & \multicolumn{2}{|l|}{ Rumia } \\
\hline & $\bar{x}$ & Min-Max & $\bar{x}$ & Min-Max \\
\hline Air temperature $\left({ }^{\circ} \mathrm{C}\right)$ & 0.9 & $-9.0-10.8$ & 1.25 & $-9.3-10.8$ \\
\hline Wind speed $\left(\mathrm{m} \mathrm{s}^{-1}\right)$ & 1.9 & $0.1-14.9$ & 2.5 & $0.1-7.5$ \\
\hline Amount of precipitation (mm) & 0.2 & $0.0-2.8$ & 14.9 & $0.0-48.3$ \\
\hline Relative humidity (\%) & 73.4 & $44.4-85.6$ & 84.52 & $44.9-98$ \\
\hline Atmospheric pressure $(\mathrm{hPa})$ & 1018.8 & $980.1-1038.6$ & 1018.7 & $980.5-1039.4$ \\
\hline
\end{tabular}

$\bar{x}$, average value 
Table 2 Concentrations of PM components measured from 22 December 2016 to 22 January 2017 in Gdynia (PM1 and PM2.5) and in Rumia (PM10)

\begin{tabular}{|c|c|c|c|c|}
\hline Parameter & Estimator & PM1 & PM2.5 & PM10 \\
\hline \multirow[t]{3}{*}{ PM } & $\mathrm{AVG} \pm \mathrm{SD}$ & $15.1 \pm 10.1$ & $20.1 \pm 12.1$ & $27.9 \pm 16.5$ \\
\hline & $\operatorname{Med} \pm\left(\mathrm{Q}_{25}-\mathrm{Q}_{75}\right)$ & $11.8 \pm(8.1-16.3)$ & $16.2 \pm(12.9-19.3)$ & $24.2 \pm(16.0-32.0)$ \\
\hline & Min-Max & $6.0-50.0$ & $8.3-61.9$ & $8.6-71.9$ \\
\hline \multirow[t]{3}{*}{$\mathrm{OC}$} & $\mathrm{AVG} \pm \mathrm{SD}$ & $4.2 \pm 4.6$ & $5.7 \pm 5.4$ & $11.7 \pm 7.9$ \\
\hline & $\operatorname{Med} \pm\left(\mathrm{Q}_{25}-\mathrm{Q}_{75}\right)$ & $3.1 \pm(1.3-6.2)$ & $4.6 \pm(2.5-8.1)$ & $8.7 \pm(6.9-13.7)$ \\
\hline & Min-Max & $0.1-20.1$ & $0.1-23.9$ & $2.8-32.8$ \\
\hline \multirow[t]{3}{*}{$\mathrm{EC}$} & $\mathrm{AVG} \pm \mathrm{SD}$ & $1.4 \pm 1.1$ & $1.7 \pm 1.3$ & $2.9 \pm 1.6$ \\
\hline & $\operatorname{Med} \pm\left(\mathrm{Q}_{25}-\mathrm{Q}_{75}\right)$ & $1.4 \pm(0.7-2.1)$ & $1.4 \pm(0.8-2.2)$ & $2.6 \pm(1.5-4.3)$ \\
\hline & Min-Max & $0.1-4.5$ & $0.1-5.1$ & $0.3-6.0$ \\
\hline \multirow[t]{3}{*}{$\mathrm{NO}_{3}^{-}$} & $\mathrm{AVG} \pm \mathrm{SD}$ & $2.2 \pm 2.3$ & $3.5 \pm 3.0$ & $3.3 \pm 2.0$ \\
\hline & $\operatorname{Med} \pm\left(\mathrm{Q}_{25}-\mathrm{Q}_{75}\right)$ & $2.2 \pm(0.6-2.5)$ & $2.2 \pm(1.3-3.9)$ & $3.2 \pm(1.8-4.5)$ \\
\hline & Min-Max & $0.1-9.2$ & $0.4-12.4$ & $0.1-6.8$ \\
\hline \multirow[t]{3}{*}{$\mathrm{SO}_{4}{ }^{2-}$} & $\mathrm{AVG} \pm \mathrm{SD}$ & $1.6 \pm 1.3$ & $2.2 \pm 2.0$ & $3.3 \pm 2.5$ \\
\hline & $\operatorname{Med} \pm\left(\mathrm{Q}_{25}-\mathrm{Q}_{75}\right)$ & $1.5 \pm(0.6-1.8)$ & $1.3 \pm(0.9-2.1)$ & $2.7 \pm(1.6-3.7)$ \\
\hline & Min-Max & $0.3-4.7$ & $0.5-8.1$ & $0.4-11.1$ \\
\hline \multirow[t]{3}{*}{ ¿PAHs } & $\mathrm{AVG} \pm \mathrm{SD}$ & $23.6 \pm 27.0$ & $32.2 \pm 33.5$ & $77.5 \pm 63.8$ \\
\hline & $\operatorname{Med} \pm\left(\mathrm{Q}_{25}-\mathrm{Q}_{75}\right)$ & $13.2 \pm(6.1-28.3)$ & $15.7 \pm(10.4-44.2)$ & $53.6 \pm(35.6-122.0)$ \\
\hline & Min-Max & $1.9-131.9$ & $2.6-153.9$ & $11.3-258.1$ \\
\hline \multirow[t]{3}{*}{ FLA } & $\mathrm{AVG} \pm \mathrm{SD}$ & $3.6 \pm 5.7$ & $5.0 \pm 6.8$ & $12.3 \pm 10.5$ \\
\hline & $\operatorname{Med} \pm\left(\mathrm{Q}_{25}-\mathrm{Q}_{75}\right)$ & $1.4 \pm(0.7-4.1)$ & $2.4 \pm(1.2-6.8)$ & $8.8 \pm(5.0-15.5)$ \\
\hline & Min-Max & $0.1-30.5$ & $0.3-37.2$ & $1.6-38.1$ \\
\hline \multirow[t]{3}{*}{ PYR } & $\mathrm{AVG} \pm \mathrm{SD}$ & $3.0 \pm 3.9$ & $4.5 \pm 5.3$ & $11.9 \pm 8.9$ \\
\hline & $\operatorname{Med} \pm\left(\mathrm{Q}_{25}-\mathrm{Q}_{75}\right)$ & $1.3 \pm(0.7-3.9)$ & $2.1 \pm(1.0-6.8)$ & $9.0 \pm(5.4-15.7)$ \\
\hline & Min-Max & $0.3-20.5$ & $0.4-23.9$ & $2.1-30.6$ \\
\hline \multirow[t]{3}{*}{$\mathrm{BaP}$} & $\mathrm{AVG} \pm \mathrm{SD}$ & $4.4 \pm 4.3$ & $5.6 \pm 5.2$ & $10.2 \pm 6.1$ \\
\hline & $\operatorname{Med} \pm\left(\mathrm{Q}_{25}-\mathrm{Q}_{75}\right)$ & $2.7 \pm(1.4-5.5)$ & $3.2 \pm(1.9-8.4)$ & $9.0 \pm(5.3-12.8)$ \\
\hline & Min-Max & $0.3-18.1$ & $0.6-21.1$ & $2.2-21.8$ \\
\hline \multirow[t]{3}{*}{ CHR } & $\mathrm{AVG} \pm \mathrm{SD}$ & $7.6 \pm 7.5$ & $10.0 \pm 9.1$ & $16.5 \pm 20.3$ \\
\hline & $\operatorname{Med} \pm\left(\mathrm{Q}_{25}-\mathrm{Q}_{75}\right)$ & $5.1 \pm(3.2-9.5)$ & $5.7 \pm(4.7-13.1)$ & $18.9 \pm(5.4-20.3)$ \\
\hline & Min-Max & $0.6-37.6$ & $0.9-42.0$ & $1.9-95.0$ \\
\hline \multirow[t]{3}{*}{$\mathrm{BaA}$} & $\mathrm{AVG} \pm \mathrm{SD}$ & $4.7 \pm 6.1$ & $6.5 \pm 7.6$ & $26.6 \pm 22.7$ \\
\hline & $\operatorname{Med} \pm\left(\mathrm{Q}_{25}-\mathrm{Q}_{75}\right)$ & $2.1 \pm(0.6-6.2)$ & $2.7 \pm(1.5-9.7)$ & $22.0 \pm(5.4-47.3)$ \\
\hline & Min-Max & $0.2-25.2$ & $0.3-29.8$ & $3.4-72.6$ \\
\hline
\end{tabular}

Garcia et al. (García et al. 2018) in Northern Spain were related to the inflow of Saharan dust with air masses from Africa. In Gdynia and Rumia between 22 December 2016 and 22 January 2017, wind direction from land sites dominated (Fig. 2). The highest concentrations of PM1 and PM2.5 in Gdynia were noted under southern and southwestern advection, which also dominated during the measurement period (together $66 \%$ of measurement time). In the case of PM10 in Rumia, it was measured under western and south-western advection, while the dominant wind direction was from the south $(30 \%)$. In both cities, the obtained results suggest that the highest concentrations of aerosols were caused by vehicle emissions from the ringroad (Fig. 1, the thick dotted line).

\section{Characterisation of PM1 and PM2.5 sources in air of Gdynia and of PM10 sources in air of Rumia during smog episodes across Poland}

Knowledge of the chemical composition of aerosols allows for the determination of air quality indicators which, together with knowledge of meteorological conditions and the direction of the inflow of air masses, can be used to determine potential sources of contaminants in the research area (Tobiszewski and Namieśnik 2012; Staniszewska et al. 2013).

In order to determine the origin of PM1 and PM2.5 in the air above Gdynia and PM10 in the air over Rumia between 22 December 2016 and 22 January 2017, the concentrations of 
a)

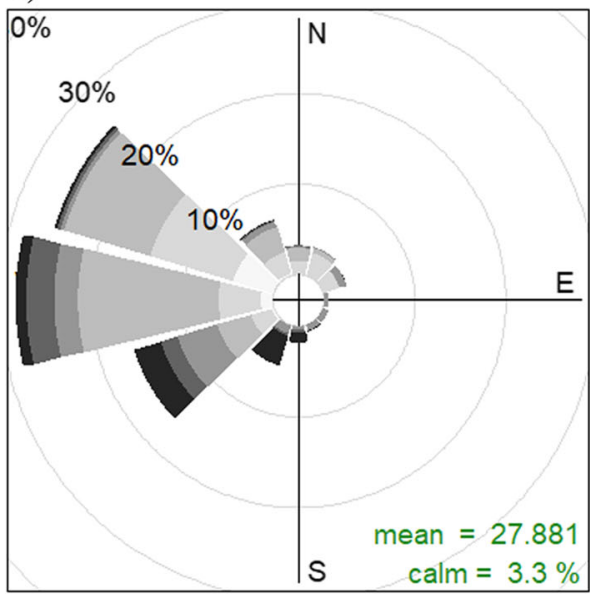

b)

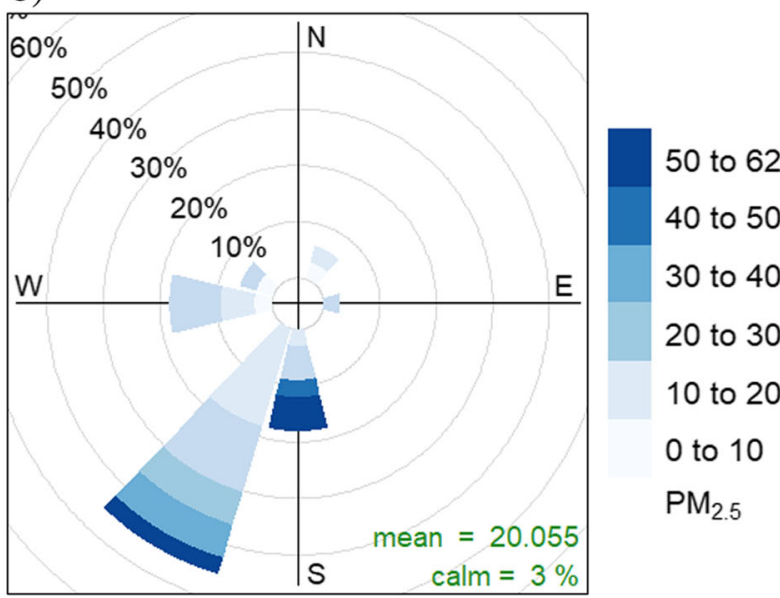

c)

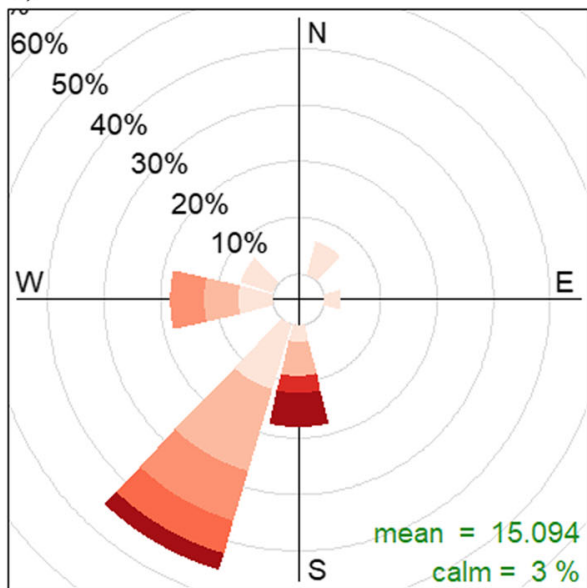

40 to 50

30 to 40

20 to 30

10 to 20

0 to 10

$\mathrm{PM}_{1}$

Fig. 2 Frequency of counts by wind direction (\%) for concentrations of a PM1 and b PM2.5 measured in Gdynia and concentrations of $\mathbf{c}$ PM10 measured in Rumia. All concentrations in $\mu \mathrm{g} \cdot \mathrm{m}^{-3}$

organic and elemental carbon were measured, as well as selected ionic components and PAHs (Table 2).

In all aerosol fractions, the highest concentrations among the analysed compounds were those of organic carbon, with the average share of OC constituting 41.0\% in PM10 (Rumia), $27.7 \%$ in PM2.5 and 27.1\% in PM1 (in Gdynia, in both cases). Earlier research conducted in Gdynia during the heating season of 2012 by Lewandowska and co-authors (Lewandowska et al. 2018 b) showed a much lower average share of OC in both aerosol fractions than in the current study $(19.1 \%$ and $19.8 \%$, for PM1 and PM2.5, respectively). However, the same tendency toward a similar percentage of OC occurring in both fractions remained. Furthermore, the share of OC in PM10 in aerosols collected in Rumia was found to be higher than that obtained during the measurements carried out in Gdynia during the late autumn of 2007 (31\% PM10) (Lewandowska et al. 2010).

A similar relationship to earlier studies was also determined in the case of EC. In the aerosols collected in Gdynia in the period from 22 December 2016 to 22 January 2017, EC constituted $9.3 \%$ of PM1 and $8.3 \%$ of PM2.5, while, in 2012, it only accounted for $6.9 \%$ and $7 \%$ of PM1 and PM2.5 mass, respectively (Lewandowska et al. 2018b). The current studies conducted in Rumia showed that EC contributed $10.3 \%$ of PM10, while, in 2007 in Gdynia, it was just $3.7 \%$ of PM10 mass (Lewandowska et al. 2010). This may indicate that, in recent years, the share of carbon, both organic and elemental, has been increasing in aerosols in the Tri-city area. The OC/ EC coefficient, in PM10 measured in Rumia ranged from 2.4 to 24.4 , indicates the source of carbon origin. These values and their amplitude were much higher than those obtained in smaller aerosols collected in Gdynia (between 1.4 and 5.9 in PM1 and between 1.2 and 6.1 in PM2.5) (Pio et al. 2008; Siciliano et al. 2018). This may indicate that, in Gdynia in PM1 and PM2.5, the share of carbon originating from communication sources was higher than in PM10 in Rumia (Keuken et al. 2013). Differences in the origin of carbon in aerosols at the two measuring stations are confirmed by a better correlation between $\mathrm{OC}$ and EC obtained in smaller aerosols in Gdynia ( $r=0.96$ for PM2.5 and $r=0.95$ for PM1) than in PM10 in Rumia $(r=0.87)$. The highest OC/ 
EC values were determined in PM10 in Rumia, and this, along with a lower correlation between the two carbonaceous compounds, indicates the greater role of secondary organic carbon in this city than in Gdynia (Siciliano et al. 2018). This in turn suggests that combustion for heating purposes may be the main pollution source in Rumia (Witkowska et al. 2016a). This source of origin was confirmed by the second of the designated indicators, the $\mathrm{NO}_{3}{ }^{-} / \mathrm{SO}_{4}{ }^{2-}$ coefficient. Among the inorganic constituents, nitrates and sulphates form a group of secondary inorganic aerosols (SIA). The main precursor gases for SIA are $\mathrm{SO}_{2}$ and $\mathrm{NOx}$, which react in the atmosphere and create aerosols. Emission of SO2 is mainly related to combustion processes and energy transformation, while road transport is key in terms of $\mathrm{NO}_{\mathrm{x}}$ emission. In Gdynia in the period from 22 December 2016 to 22 January 2017, $\mathrm{NO}_{3}{ }^{-}$ dominated over $\mathrm{SO}_{4}{ }^{2-}$ in both PM1 and PM2.5 (Table 2). The average $\mathrm{NO}_{3}{ }^{-} / \mathrm{SO}_{4}{ }^{2-}$ ratio in PM1 and PM2.5 was equal to 1.6 and 1.4, respectively. This indicates that, in Gdynia, transport could be the main source of aerosols (Wang et al. 2006; Lai et al. 2007). In Rumia, concentrations of $\mathrm{NO}_{3}{ }^{-}$and $\mathrm{SO}_{4}{ }^{2-}$ were on average the same, and the mean $\mathrm{NO}_{3}{ }^{-} / \mathrm{SO}_{4}{ }^{2-}$ ratio was equal to 1.1 , suggesting the more important role of combustion for heating purposes in the formation of aerosols.

In order to ascertain the origin of aerosols in Gdynia and Rumia during periods of high concentrations, the concentrations and proportions between selected PAHs were determined. Polycyclic aromatic hydrocarbons (PAHs) are a group of organic compounds which are widespread contaminants in the environment, created among other things by incomplete combustion of fossil fuels and biomass. Energy and industrial sources also contribute to the pollution of the atmosphere with these compounds, and they are a constituent of coke smoke (Arnott et al. 2005; Tolis et al. 2015). The presence of benzo(a)pyrene in aerosols in Gdynia and Rumia is very important as it is the major indicator of the pollution by those organic aerosol compounds. The acceptable concentration for this compound in PM10 in EU countries is $1 \mathrm{ng} \mathrm{m}^{-3}$ (Directive 2004/107/WE). In Gdynia and Rumia, the average values were higher than $1 \mathrm{ng} \mathrm{m}^{-3}$ in every aerosol fraction (Table 2). Studies conducted by Jakovljević et al. (2018) from January 2013 to December 2013 in Zagreb (Croatia) showed similar results to ours with maximum concentrations of $\mathrm{BaP}$ in PM1 (10.3 $\left.\mathrm{ng} \mathrm{m}^{-3}\right)$, in PM2.5 (27.2 $\left.\mathrm{ng} \mathrm{m}^{-3}\right)$ and in PM10 $\left(29.3 \mathrm{ng} \mathrm{m}^{-3}\right.$ ) (Table 2). In other regions of Poland, like in the urban area of Silesia, BaP concentrations are also elevated. For example, measurements conducted by RogulaKozłowska and co-authors (Rogula-Kozłowska et al. 2013) from 2007 to 2008 showed average BaP concentrations to be $16.1 \mathrm{ng} \mathrm{m}^{-3}$ (PM1), $19.2 \mathrm{ng} \mathrm{m}^{-3}$ (PM2.5) and $19.3 \mathrm{ng} \mathrm{m}^{-3}$ (PM10). The measurements conducted in Gdynia showed a very important dependence with up to $85 \%$ of BaP present in PM2.5 being a part of PM1 (Table 2). This proves the importance of PM1 monitoring, even in seaside cities/towns like Gdynia and Rumia where aerosol concentrations are much lower than in the rest of Poland. In every aerosol fraction, even the lower quartiles of $\mathrm{BaP}$ concentration were above $1 \mathrm{ng} \mathrm{m}^{-3}$. Thus, our results complement a lack of papers describing PAHs in PM1 (Jakovljevi et al. Jakovljević et al. 2018).

In the period from 22 December 2016 to 22 January 2017, five PAHs were analysed. Among these, chrysene was found to have the highest concentration in both PM1 and PM2.5 measured in Gdynia (Table 2). The presence of CHR is related usually to the combustion of fuels for transport purposes, with emphasis on diesel engines (Bourotte et al. 2005; Teixeira et al. 2012). Benzo(a)anthracene, which dominated in PM10 in Rumia, has carcinogenic and teratogenic properties. The sources of emission for this compound include combustion of gasoline and diesel oil and emission from asphalt, as well as combustion of coal for heating purposes (Ravindra et al. 2008). Similarly, to the previously described OC/EC and $\mathrm{NO}_{3}{ }^{-} / \mathrm{SO}_{4}{ }^{2-}$ coefficients, this suggests transport and combustion in the municipal and residential sectors as being the two most important sources of air pollution in Rumia and Gdynia. These sources of origin for aerosols, both in Gdynia and Rumia, have been proven by designated PAH indicators. The first of these was the ratio of FLA/(FLA+PYR). Values between 0.4 and 0.5 , suggesting liquid fuel combustion, were noted for $31 \%$ of the measurement period in Gdynia (for both PM1 and PM2.5), and in Rumia, it was even higher (37\% of PM10 measurement time). Values above 0.5 , suggesting coal or wood combustion for heating purposes, constituted $53 \%$ and $59 \%$ of measurement time in Gdynia for PM1 and PM2.5, respectively. In PM10 in Rumia, meanwhile, it was equal to $52 \%$ of the measurement period. The rest, $16 \%$ in PM1 to $10 \%$ in PM2.5 and 11\% in PM10, suggest petrogenic sources (oil combustion mainly) (Arnott et al. 2005). At such times, the dominant source of aerosols containing fluoranthene and pyrene could have been wood and coal combustion for heating purposes but in the smallest particles, the increased role of transport was clearly defined (Tobiszewski and Namieśnik 2012).

The second ratio, $\mathrm{BaA} /(\mathrm{BaA}+\mathrm{CHR})$, indicated petrogenic sources in aerosols when below 0.35 (Arnott et al. 2005). During the measurement period in Gdynia, such values were noted for $44 \%$ of the time in PM1 and $41 \%$ of the time in PM2.5, while, in Rumia, they only accounted for $11 \%$ of PM10 measurements. Ratio values above 0.35 , which are linked to coal or wood combustion processes, were noted for $41 \%$ of the time with PM1, $50 \%$ with PM2.5 and as much as $88 \%$ for PM10. The ratio of $\mathrm{BaP} /(\mathrm{BaP}+\mathrm{CHR})$ further distinguishes diesel vehicles $(<$ $0.5)$ from gasoline vehicles $(>0.5)$. Both in Rumia and Gdynia, diesel was found to be more important in dictating air quality than gasoline, with median $\mathrm{BaP} /(\mathrm{BaP}+\mathrm{CHR})$ ratios of 0.37 in PM1 and PM2.5 and 0.48 in PM10 
(Tobiszewski and Namieśnik 2012). According to Silveira and co-authors (Silveira et al. 2017), diesel has the highest emission factor from different types of fuels for $\mathrm{NO}_{\mathrm{x}}, \mathrm{PM} 2.5$ and PM10 so those cars represent an important problem requiring further efforts at improvement. Currently in Europe, there is a trend toward recalling diesel cars and many large cities such as Oslo, Paris, Hamburg and Prague forbid such vehicles from entering the city centres. However, diesel cars from more developed countries than Poland are then brought here to be sold on. Pomerania, the voivodeship in which the Tri-city is located, is tenth on the list of Polish voivodeships with the highest number of registered used cars - 7165 cars in January and February 2016. In the whole country in 2016, about 783,000 were imported, of which $41.9 \%$ were diesel (Institute of Automotive Market Research, https://www.samar.pl/).

\section{Episodes of high PM1 and PM2.5 concentrations in the air over Gdynia and PM10 in the air over Rumia}

In Gdynia in the period between 22 December 2016 and 22 January 2017, four episodes of high aerosol concentration were noted, while, in Rumia, there were three. The first day to feature high PM1 $\left(41.1 \mu \mathrm{g} \cdot \mathrm{m}^{-3}\right)$ and PM2.5 $\left(52 \mu \mathrm{g} \cdot \mathrm{m}^{-3}\right)$ concentrations in Gdynia was 22 December 2016, just before Christmas. On that occasion, meteorological conditions fostered the bad air quality and with wind reaching $1.8 \mathrm{~m} \mathrm{~s}^{-1}$ and temperature peaking at $4{ }^{\circ} \mathrm{C}, \mathrm{BaP}$ concentration was found to be the highest at a level of $21.1 \mathrm{ng} \mathrm{m}^{-3}$. Staniszewska and co-authors (Staniszewska et al. 2013) obtained similar values of $\mathrm{BaP}$ in aerosols $\left(25.2 \mathrm{ng} \mathrm{m}^{-3}\right)$ during measurements in Gdynia in the period before Christmas and New Year's Day. Diagnostic ratios $\left(\mathrm{NO}_{3} / \mathrm{SO}_{4}{ }^{2-} 2.7\right.$ in PM1, and 2.1 in $\mathrm{PM} 2.5 ; \mathrm{BaP} /(\mathrm{BaP}+\mathrm{CHR})$ equal to 0.45 in both fractions) suggest the conclusion that before Christmas and New Year's Day transport plays a key role in creating air quality in Gdynia and this is consistent with earlier results (Staniszewska et al. 2013; Witkowska et al. 2016a).

The other episodes of high aerosol concentration in Gdynia occurred on 9 January 2017 (28.4 and $32.452 \mu \mathrm{g} \cdot \mathrm{m}^{-3}$ for PM1 and PM2.5, respectively), 10 January 2017 (35.2 and 43.6 $52 \mu \mathrm{g} \cdot \mathrm{m}^{-3}$ for PM1 and PM2.5, respectively) and 11 January 2017 (50 and $61.952 \mu \mathrm{g} \cdot \mathrm{m}^{-3}$ for PM1 and PM2.5, respectively). The poor air quality experienced during this period may be attributed to continued vehicle emissions combined with a low temperature $\left(-9{ }^{\circ} \mathrm{C}\right)$ which was favourable for intensified heating. However, elevated PM concentrations were also noted across the whole country at this time, reaching their maximum values on 8 January. Forty-eight-hour HYSPLIT backward trajectories obtained for the described period showed that high concentrations of PM1 and PM2.5 in Gdynia may have been strengthened by more polluted air coming in from over southern parts of the country (Fig. 3). Rapid increase in aerosol concentrations in regions of potentially cleaner air due to the transportation of pollutants with air masses has been also reported by Oliveira et al. (2018).

The extreme values of the sum of analysed PAHs in PM1 (131.9 $\mathrm{ng} \mathrm{m}^{-3}$ ) and PM2.5 (153.9 $\mathrm{ng} \mathrm{m}^{-3}$ ) measured in Gdynia were noted on 11 January. On the same day, the highest concentration of CHR was recorded in PM1 and PM2.5 (37.6 $\mathrm{ng} \mathrm{m}^{-3}$ and $42.0 \mathrm{ng} \mathrm{m}^{-3}$, respectively), the presence of which is associated with the combustion of fuels for transport purposes, especially in diesel engines. The $\mathrm{NO}_{3}{ }^{-} /$ $\mathrm{SO}_{4}{ }^{2-}$ ratio was also high (2.4 and 1.5 for PM1 and PM2.5, respectively).

In Rumia, high concentrations of PM10 also occurred in the period between 8 and 11 January 2017, with the higher concentrations being noted on 8 January $2017\left(71.9 \mu \mathrm{g} \cdot \mathrm{m}^{-3}\right)$, 10 January $2017\left(66.4 \mu \mathrm{g} \cdot \mathrm{m}^{-3}\right)$ and 11 January $2017(61.9 \mu \mathrm{g}$. $\mathrm{m}^{-3}$ ) (Fig. 4). BaP in PM10 reached its maximum concentration of $21.8 \mathrm{ng} \mathrm{m}^{-3}$ on 10 January, and this was almost as high as the maximum BaP concentration in Gdynia in the finest aerosol.

Analysis of the obtained coefficients and the prevailing meteorological conditions allowed us to establish that, in Rumia, high concentrations of aerosols were associated with a greater extent with the combustion of fuels for heating purposes than with emissions from transport sources. This is indicated by several ratios $\left(\mathrm{NO}_{3}{ }^{-} / \mathrm{SO}_{4}{ }^{2-} 0.9, \mathrm{OC} / \mathrm{EC} 5.5, \mathrm{FLA} /\right.$ (FLA+PYR) 0.5). However, on 10 and 11 January, mass advection changed and as in Gdynia, advection from the south brought polluted air masses.

During this study, an episode of very low concentration also occurred when, from 26 to 28 January, Barbara Hurricane lashed the Gulf of Gdansk. On those days, the temperature reached $10{ }^{\circ} \mathrm{C}$ and wind speed reached $14.9 \mathrm{~m} \mathrm{~s}^{-1}$. Over the open sea and the Gulf of Gdansk, the wind blew with a force of up to $110 \mathrm{~km} \mathrm{~h}^{-1}$, while, over land, the maximum noted velocity was about $80 \mathrm{~km} \mathrm{~h}^{-1}$. The onset of this hurricane under northern advection could be partly responsible for the lowest PM concentration noted (PM1 6.8-9.4 $\mu \mathrm{g} \cdot \mathrm{m}^{-3}$, PM2.5 9.7-18.3 $\mu \mathrm{g} \cdot \mathrm{m}^{-3}$, PM10 8.6-25.7 $\mu \mathrm{g} \cdot \mathrm{m}^{-3}$ ) and generally lower concentrations at the end of the year.

\section{Conclusions}

At the end of 2016 and beginning of 2017, when several severe smog episodes were noted across the whole of Poland, PM1 and PM2.5 concentrations measured in Gdynia as well as PM10 concentrations obtained in Rumia were significantly lower than those in other parts of the country. However even here, in close proximity to the sea, there were a few occurrences of high daily aerosol concentrations. 
Fig. 3 PM2.5 concentration $\left(\mu \mathrm{g} \cdot \mathrm{m}^{-3}\right)$ at the Inspectorate of Environmental Protection stations (IEP) on 8 January 2017 and 48-h backward mass trajectories (HYSPLIT) at the Gdynia station

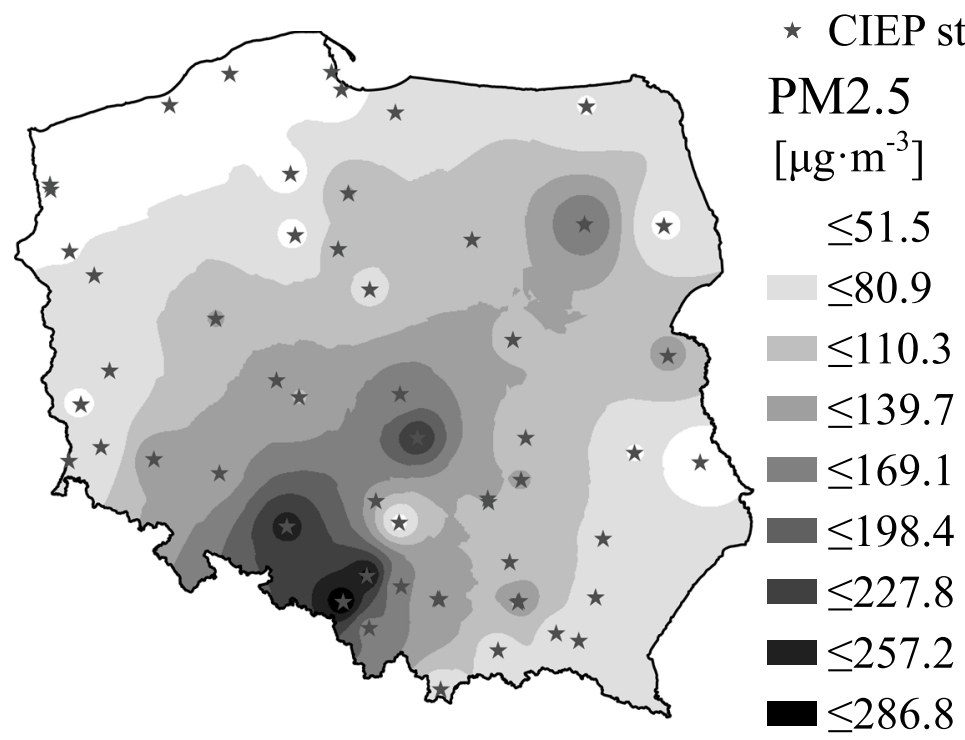

$9^{\text {th }}$ of January, 2017
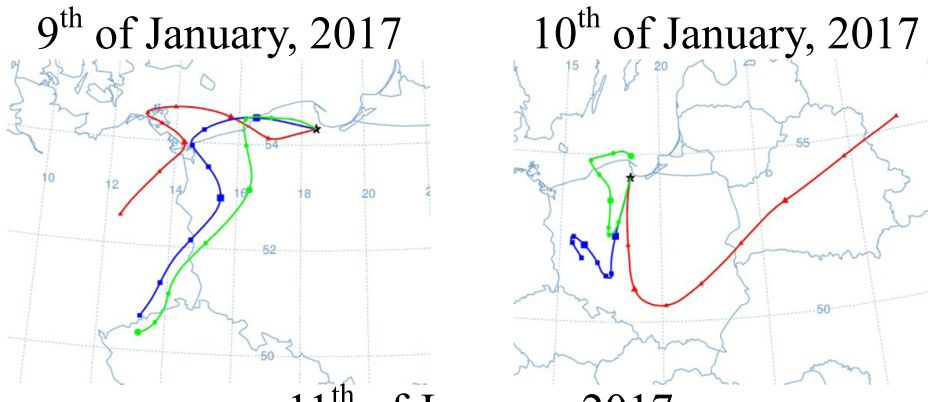

Obtained results indicated that, in the space of a few years, the share of organic and elemental carbon in aerosols of all sizes has increased. This may mean that carbon emissions in the region in the near future may become the dominant problem in terms of air quality.

Air quality measurements took place during the heating period; hence, coal and wood combustion for heating purposes had a significant impact on air quality in both Gdynia and Rumia. However, its role as key source was more pronounced in Rumia, where individual heating systems dominate. In Gdynia, it was land transport, with a particular emphasis on diesel engines, which had the most conspicuous impact on air quality.

The measurements conducted in Gdynia showed that up to $85 \%$ of BaP (which is toxic for humans) present in PM2.5 was also a part of PM1. This proves the importance of PM1 monitoring even in places located in close proximity to the sea, where concentrations of aerosols are usually much lower than in highly polluted regions.

During the study period, a few instances of high daily aerosol concentrations were noted in Gdynia and in Rumia. In Gdynia, this was due to transportation of polluted air from southern Poland, but also very low temperatures which led to a rapid increase of emissions from the residential sector. Before Christmas, heightened concentrations of nitrates and carbon compounds (including toxic $\mathrm{BaP}$ and $\mathrm{BaA}$ ) were mainly as a result of transport emissions. In Rumia, despite its location, there were higher concentrations of PM10 and these were brought about principally by local and regional emissions, especially combustion processes for heating purposes. 


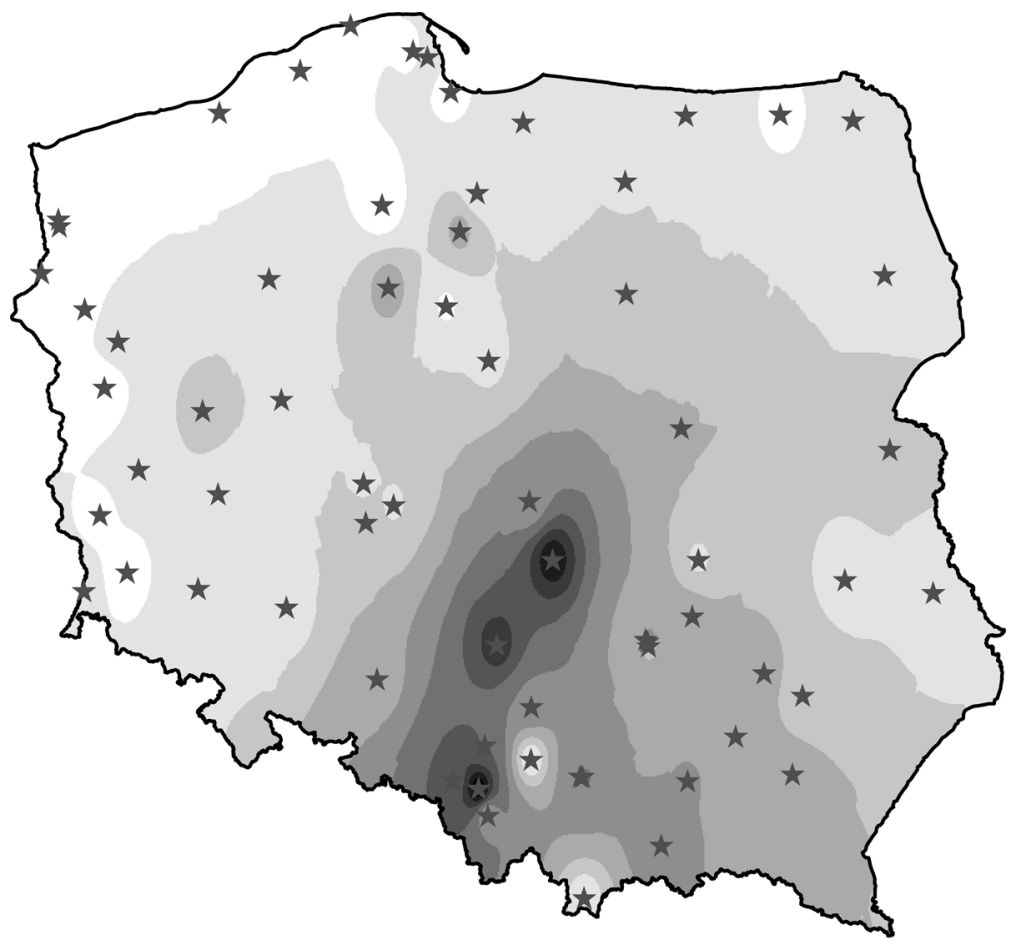

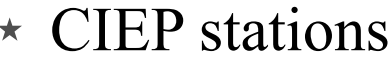

PM10 $\left[\mu \mathrm{g} \cdot \mathrm{m}^{-3}\right]$

$\leq 62.3$

$\leq 95.3$

$\leq 128.3$

$\leq 161.3$

$\leq 194.3$

$\leq 227.3$

$\leq 260.3$

$\leq 293.3$

$\boldsymbol{m} \leq 326.3$

$\boldsymbol{m} \leq 359.3$

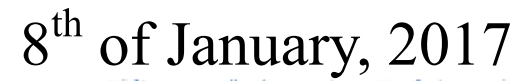

$10^{\text {th }}$ of January, 2017

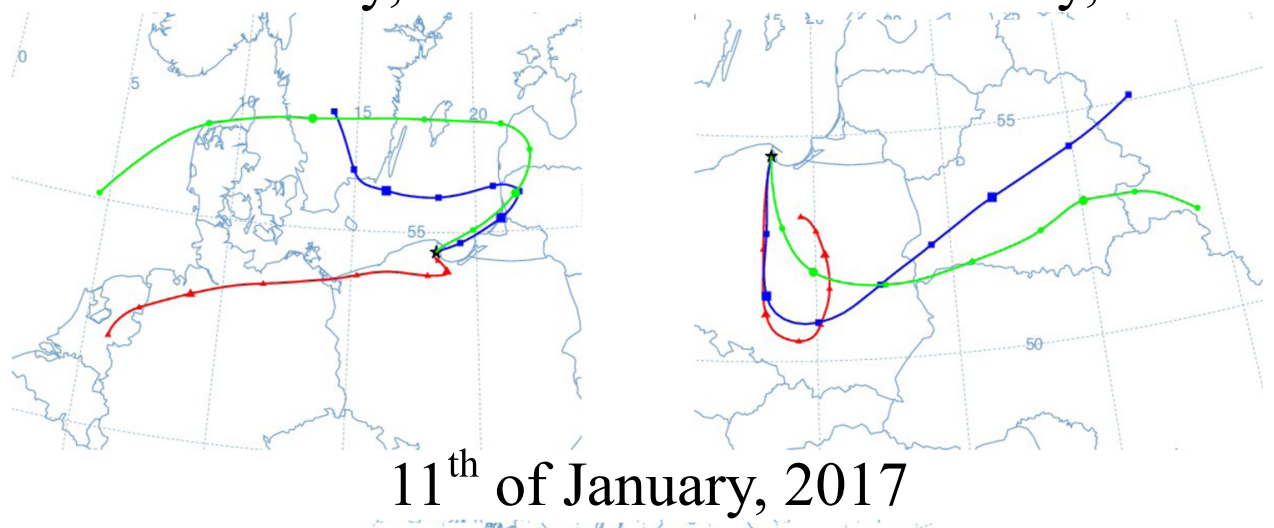

Fig. 4 PM10 concentration $\left(\mu \mathrm{g} \cdot \mathrm{m}^{-3}\right)$ at the Inspectorate of Environmental Protection stations (IEP) on 8 January 2017 and 48 -h backward mass trajectories (HYSPLIT) at the Rumia station 
The episode of very low concentration which happened during the study period may be attributed to the onset of a hurricane under northern advection at the end of the year.

Acknowledgements The meteorological data and PM10 aerosol samples presented in this publication have been made available free of charge and remain the property of the Agency for Regional Atmosphere Monitoring of the Gdansk Agglomeration ARMAAG.

Open Access This article is distributed under the terms of the Creative Commons Attribution 4.0 International License (http:// creativecommons.org/licenses/by/4.0/), which permits unrestricted use, distribution, and reproduction in any medium, provided you give appropriate credit to the original author(s) and the source, provide a link to the Creative Commons license, and indicate if changes were made.

\section{References}

Alves CA, Vicente AM, Custódio D, Cerqueira M, Nunes T, Pio C, Lucarelli F, Calzolai G, Nava S, Diapouli E, Eleftheriadis K, Querol X, Musa Bandowe BA (2017) Polycyclic aromatic hydrocarbons and their derivatives (nitro-PAHs, oxygenated PAHs, and azaarenes) in PM2.5 from southern European cities. Sci Total Environ 595:494 504. https://doi.org/10.1016/j.scitotenv.2017.03.256

Arnott W, Zielinska B, Rogers C, Sagebiel J, Park K, Chow J, Moosmuller H, Watson J, Kelly K, Wagner D, Sarofim A, Lighty J, Palmer G (2005) Evaluation of $1047 \mathrm{~nm}$ photoacoustic instruments and photoelectric aerosol sensors in source-sampling of black carbon aerosol and particle-bound PAHs from gasoline and diesel powered vehicles. Environ Sci Technol 39:5398-5406. https://doi. org/10.1021/es049595e

Awe Y, Nygard J, Larssen S, Lee H, Dulal H, Kanakia R, (2015) Clean air and healthy lungs: enhancing the World Bank's approach to air quality management (English), vol. 1, pp. 130

Bourotte C, Forti MC, Taniguchi S, Bícego MC, Lotufo PA (2005) A wintertime study of PAHs in fine and coarse aerosols in São Paulo city, Brazil. Atmos Environ 39:3799-3811. https://doi.org/10.1016/ j.atmosenv.2005.02.054

Bruce N, Perez-Padilla R, Albalak R (2000) Indoor air pollution in developing countries: a major environmental and public health challenge. Environ Health 78:1078-1092

Carslaw DC, Ropkins K (2012) Openair - an R package for air quality data analysis. Environ Modell Soft 27-28:52-61

Cavalli F, Viana M, Yttri KE, Genberg J, Putaud JP (2010) Toward a standardised thermal-optical protocol for measuring atmospheric organic and elemental carbon: the EUSAAR protocol. Atmos Meas Tech 3:79-89. https://doi.org/10.5194/amt-3-79-2010

Chen W, Li A, Zhang F (2018) Roadside atmospheric pollution: still a serious environmental problem in Beijing, China. Air Qual Atmos Health 11:1203-1216. https://doi.org/10.1007/s11869-018-0620-2

CIEP (Chief Inspectorate of Environmental Protection) (2016) Fine dust in the atmosphere. A compendium of knowledge about air pollution particulate matter in Poland. http://www.gios.gov.pl/images/ aktualnosci/Pyly_drobne_w_atmosferze.Kompendium_wiedzy.pdf. Accessed 24 October 2018

Ćwiklak K, Pastuszka JS, Rogula-Kozlowska W (2009) Influence of traffic on particulate-matter polycyclic aromatic hydrocarbons in urban atmosphere of Zabrze. Poland Polish J Environ Stud 18: $579-585$

EEA, European Environment Agency (2014) Air quality in Europe 2014 report. Luxembourg: Publications Office of the European Union, pp. 84. https://doi.org/10.2800/22775
Falkowska L, Lewandowska A (2004) Sulphates in particles of different sizes in the marine boundary layer over the southern Baltic Sea. Oceanologia 46:1-15

García MÁ, Sánchez ML, de los Ríos A, Pérez IA, Pardo N, FernándezDuque B (2018) Analysis of PM10 and PM2.5 concentrations in an urban atmosphere in northern Spain. Arch Environ Contam 76:331345. https://doi.org/10.1007/s00244-018-0581-3

Gordon T, Balakrishnan K, Dey S, Rajagopalan S, Thornburg J, Thurston G, Agrawal A, Collman G, Guleria R, Limaye S, Salvi S, Kilaru V, Nadadur S (2018) Air pollution health research priorities for India: perspectives of the Indo- U.S. Communities of Researchers. Environ Int 119:100-108. https://doi.org/10.1016/j.envint.2018.06.013

Hassanvand MS, Naddafi K, Faridi S, Nabizadeh R, Sowlat MH, Momeniha F, Gholampour A, Arhami M, Kashani H, Zare A, Niazi S, Rastkari N, Nazmara S, Ghani M, Yunesian M (2015) Characterization of PAHs and metals in indoor/outdoor PM10 /PM2.5/PM1 in a retirement home and a school dormitory. Sci Total Environ 527-528:100-110. https://doi.org/10.1016/j. scitotenv.2015.05.001

Jakovljević I, Pehnec G, Vađić V, Čačković M, Tomašić V, Doko Jelinić J (2018) Polycyclic aromatic hydrocarbons in PM10, PM2.5 and PM1 particle fractions in an urban area. Air Qual Atmos Health 11:843854. https://doi.org/10.1007/s11869-018-0603-3

Kennedy IM (2007) The health effects of combustion-generated aerosols. Proc Combust Inst 31:2757-2770. https://doi.org/10.1016/j.proci. 2006.08.116

Keuken M, Zandveld P, Jonkers S, Moerman M, Jedynska A, Verbeek R, Visschedijk A, Elshout S, Panteliadis P, Velders G (2013) Modelling elemental carbon at regional, urban and traffic locations in the Netherlands. Atmos Environ 73:73-80. https://doi.org/10.1016/j. atmosenv.2013.03.010

KOBIZE (The National Centre for Emissions Management) (2016) Krajowy bilans emisji SO2, NOx, CO, NH3, NMLZO, pyłów, metali ciężkich i TZO za lata 2013-2014 w układzie klasyfikacji SNAP i NFR. Raport podstawowy. http://www.kobize.pl/uploads/ materialy/materialy_do_pobrania/krajowa_inwentaryzacja_emisji/ Bilans_emisji_raport_syntetyczny 2015.pdf Accessed 13 October 2018

KOBIZE (The National Centre for Emissions Management) (2018) Krajowy bilans emisji SO2, NOx, CO, NH3, NMLZO, pyłów, metali ciężkich i TZO za lata 2015-2016 w układzie klasyfikacji. SNAP. Raport syntetyczny http://www.kobize.pl/uploads/materialy/ materialy_do_pobrania/krajowa_inwentaryzacja_emisji/Bilans emisji za 2016 -raport syntetyczny.pdf Accessed 14 October $201 \overline{8}$

Lai S, Cao J, Lee S, Ho K (2007) Characterizing ionic species in PM 2,5 and PM 10 in four Pearl River Delta cities, South China. J Environ Sci 19: 939-947. https://doi.org/10.1016/S1001-0742(07)60155-7

Lewandowska A, Falkowska L, Murawiec D, Pryputniewicz D, Burska D, Bełdowska M (2010) Elemental and organic carbon in aerosols over urbanized coastal region (southern Baltic Sea, Gdynia). Sci Total Environ 408:4761-4769. https://doi.org/10.1016/j.scitotenv. 2010.06.017

Lewandowska A, Falkowska L, Jóźwik J (2013) Factors determining the fluctuation of fluoride concentrations in PM10 aerosols in the urbanized coastal area of the Baltic Sea (Gdynia, Poland). Environ Sci Pollut Res 20:6109-6118

Lewandowska AU, Bełdowska M, Witkowska A, Falkowska L, Wiśniewska K (2018a) Mercury bonds with carbon (OC and EC) in small aerosols (PM1) in the urbanized coastal zone of the Gulf of Gdansk (southern Baltic). Ecotoxicol Environ Saf 157:350-357. https://doi.org/10.1016/j.ecoenv.2018.03.097

Lewandowska AU, Staniszewska M, Witkowska A, Machuta M, Falkowska L (2018b) Benzo(a)pyrene parallel measurements in PM1 and PM2.5 in the coastal zone of the Gulf of Gdansk (Baltic Sea) in the heating and non-heating seasons. Environ Sci Pollut Res 25:19458-19469. https://doi.org/10.1007/s11356-018-2089-9 
NFZ, National Health Fund (2018) Analysis of the reasons for the increase in the number of deaths in Poland in 2017. Department of Analysis and Strategy, pp. 9 (in polish)

Oliveira RL, Custódio DJ, de Rainho CR, Morais E, Felzenszwalb I, Corrêa S, Débora A, Arbilla G (2018) Polycyclic aromatic hydrocarbon patterns in the City of Rio de Janeiro. Air Qual Atmos Health 1:1-10. https://doi.org/10.1007/s11869-018-0566-4

Pio CA, Legrand M, Alves CA, Oliveira T, Afonso J, Caseiro A, Puxbaum H, Sanchez-Ochoa A, Gelencsér A (2008) Chemical composition of atmospheric aerosols during the 2003 summer intense forest fire period. Atmos Environ 42:7530-7543. https://doi.org/10. 1016/j.atmosenv.2011.08.045

Ravindra K, Sokhi R, Van Grieken R (2008) Atmospheric polycyclic aromatic hydrocarbons: source attribution, emission factors and regulation. Atmos Environ 42:2895-2891. https://doi.org/10.1016/j. atmosenv.2007.12.010

Reizer M, Juda-Rezler K (2016) Explaining the high PM10 concentrations observed in polish urban areas. Air Qual Atmos Health 9:517531. https://doi.org/10.1007/s11869-015-0358-z

Rogula-Kozłowska W, Kozielska B, Klejnowski K (2013) Hazardous compounds in urban pm in the central part of Upper Silesia (Poland) in winter. Arch Environ Prot 39:53-65

Rogula-Kozłowska W, Klejnowski K, Rogula-Kopiec P, Ośródka L, Krajny E, Błaszczak B, Mathews B (2014) Spatial and seasonal variability of the mass concentration and chemical composition of PM2.5 in Poland. Air Qual Atmos Health 7:41-58

Schmid H, Lasku L, Abraham HJ, Baltensperger U et al (2001) Results of the "carbon conference" international aerosol carbon round robin test stage I. Atmos Environ 35:2111-2121. https://doi.org/10.1016/ S1352-2310(00)00493-3

Siciliano T, Siciliano M, Malitesta C, Proto A, Cucciniello R, Giove A, Iacobellis S, Genga A (2018) Carbonaceous PM10 and PM2.5 and secondary organic aerosol in a coastal rural site near Brindisi (southern Italy). Environ Sci Pollut Res 25:23929-23945. https://doi.org/ 10.1007/s11356-018-2237-2

Silveira C, Ferreira J, Monteiro A, Miranda AI, Borrego C (2017) Emissions from residential combustion sector: how to build a high spatially resolved inventory. Air Qual Atmos Health 11:1-12. https://doi.org/10.1007/s11869-017-0526-4

Staniszewska M, Graca B, Bełdowska M, Saniewska D (2013) Factors controlling benzo(a)pyrene concentration in aerosols in the urbanized coastal zone. A case study: Gdynia, Poland (southern Baltic Sea). Environ Sci Pollut Res 20:4154-4163

Szewczyńska M, Pośniak M, Dobrzyńska E, Pyrzyńska K, Baraniecka J (2013) Polycyclic aromatic hydrocarbons distribution in fine and ultrafine particles emitted from diesel engines. Pol J Environ Stud 22:553-560

Teixeira EC, Agudelo-Castañeda DM, Fachel JMG, Leal KA, Garcia KO, Wiegand F (2012) Source identification and seasonal variation of polycyclic aromatic hydrocarbons associated with atmospheric fine and coarse particles in the metropolitan area of Porto Alegre, RS, Brazil. Atmos Res 118:390-403. https://doi.org/10.1016/j.atmosres. 2012.07.004

Tobiszewski M, Namieśnik J (2012) PAH diagnostic ratios for the identification of pollution emission sources. Environ Pollut 22(162): 110-119. https://doi.org /10.1016/j.envpol.2011.10.025 110-119

Tolis EI, Saraga DE, Filiou KF, Tziavos NI, Tsiaousis CP, Dinas A, Bartzis JG (2015) One-year intensive characterization on PM2.5 nearby port area of Thessaloniki. Greece Environ Sci Pol Res 22: 6812-6826. https://doi.org/10.1007/s11356-014-3883-7

Torres P, Ferreira J, Monteiro A, Costa S, Pereira MC, Madureira J, Mendes A, Teixeira JP (2018) Air pollution: a public health approach for Portugal. Sci Total Environ 643:1041-1053. https://doi. org/10.1016/j.scitotenv.2018.06.281

Wang Y, Zhuang G, Zhang X (2006) The ion chemistry, seasonal cycle, and sources of PM2.5 and TSP aerosol in Shanghai. Atmos Environ 40:2935-2952. https://doi.org/10.1016/j.atmosenv.2005.12.051

Wiśniewska K, Lewandowska AU, Witkowska A (2017) Factors determining dry deposition of total mercury and organic carbon in house dust of residents of the Tri-city and the surrounding area (Baltic Sea coast). Air Qual Atmos Health 10:821-832. https://doi.org/10.1007/ s11869-017-0471-2

Witkowska A, Lewandowska AU, Saniewska D, Falkowska LM (2016a) Effect of agriculture and vegetation on carbonaceous aerosol concentrations (PM2.5 and PM10) in Puszcza Borecka National Nature Reserve (Poland). Air Qual Atmos Health 9:761-773. https://doi. org/10.1007/s11869-015-0378-8

Witkowska A, Lewandowska A, Falkowska L (2016b) Parallel measurements of organic and elemental carbon dry (PM1, PM2.5) and wet (rain, snow, mixed) deposition into the Baltic Sea. Mar Pollut Bull 15:303-312. https://doi.org/10.1016/j.marpolbul.2016.01.003

Publisher's note Springer Nature remains neutral with regard to jurisdictional claims in published maps and institutional affiliations. 